\title{
Calcium/Calmodulin-Dependent Protein Kinase Type 1
}

National Cancer Institute

\section{Source}

National Cancer Institute. Calcium/Calmodulin-Dependent Protein Kinase Type 1. NCI

Thesaurus. Code C116671.

Calcium/calmodulin-dependent protein kinase type 1 (370 aa, $\sim 41 \mathrm{kDa}$ ) is encoded by the human CAMK1 gene. This protein plays a role in both calcium/calmodulin-dependent signaling pathways and protein phosphorylation. 